\title{
Immunoglobulin E and G4 epitopes of the major allergen of birch pollen Bet $v 1$ share residues critical for antibody binding
}

\author{
N Groh ${ }^{1}$, B Subbarayal ${ }^{2}$, L Vogel ${ }^{1}$, C Möbs ${ }^{3}$, NW de Jong ${ }^{4}$, W Pfützner ${ }^{3}$, RG van Wijk${ }^{4}$, J Lidholm ${ }^{5}$, L Meisel ${ }^{1}$, \\ S Randow ${ }^{1}$, T Holzhauser $^{1}$, B Bohle ${ }^{2}$, S Vieths ${ }^{1}$, D Schiller ${ }^{1^{*}}$ \\ From Food Allergy and Anaphylaxis Meeting (FAAM 2013) \\ Nice, France. 7-9 February 2013
}

\section{Background}

Millions of patients with allergy to birch pollen develop clinically cross-reactive IgE against Bet $\mathrm{v}$ 1-like proteins in plant foods. Specific immunotherapy (SIT) with birch pollen extracts induces the biosynthesis of Bet $v$ 1-specific immunoglobulin $(\mathrm{Ig}) \mathrm{G}_{4}$. $\mathrm{IgG}_{4}$ is believed to act as a blocking antibody preventing IgE binding to Bet $\mathrm{v} 1$, thus alleviating allergic symptoms. Only little information on the location and relationship of $\operatorname{IgE}$ and $\operatorname{IgG}_{4}$ binding sites of Bet $\mathrm{v} 1$ is available. In this study we seek to identify epitopes of IgE and $\operatorname{IgG}_{4}$ antibodies on Bet $v 1$.

\section{Methods}

A competitive immunoscreening of phage-displayed peptides was applied to predict Bet $\mathrm{v} 1$ epitopes of allergen-specific IgE and $\mathrm{IgG}_{4}$ antibodies by bioinformatic means. Predicted epitope residues potentially critical for antibody binding were substituted by site-directed mutagenesis. Recombinant Bet v 1 (rBet v 1) and rBet v 1 variants were purified from Escherichia coli. The proteins were physicochemically characterized using circular dichroism $(\mathrm{CD})$ and dynamic light scattering. To test the $\mathrm{IgE}$ and $\mathrm{IgG}_{4}$ interactions with rBet $\mathrm{v} 1$ variants, western blot analyses, ELISA, and cellular mediator release assays were performed.

\section{Results}

Several rBet v 1 variants were expressed in E. coli. Circular dichroism and structural modeling of the variants revealed Bet $\mathrm{v}$ 1-like theoretical secondary structure topology. The rBet v 1 variants showed reduced IgE and $\mathrm{IgG}_{4}$ binding with sera of birch pollen allergic subjects in western blot analyses and competitive ELISAs. The rBet v 1 variants showed decreased IgE-mediated mediator release in humanized rat basophil leukemia cells sensitized with sera of birch pollen allergic subjects.

\section{Conclusion}

We identified critical residues in $\operatorname{IgE}$ and $\mathrm{IgG}_{4}$ epitopes of Bet v 1. Although patient-specific variability was observed, the antibody interactions of the respective rBet $\mathrm{v} 1$ variants were compromised for both IgE and $\mathrm{IgG}_{4}$, respectively. We conclude that epitopes for $\operatorname{IgE}$ and $\mathrm{IgG}_{4}$ share common residues critical for antibody interaction, suggesting an overlap of $\operatorname{IgE}$ and $\mathrm{IgG}_{4}$-binding sites on the molecular surface of Bet $\mathrm{v} 1$. The knowledge of clinically relevant immunoglobulin-allergen interactions on the molecular level enables new strategies in the diagnosis, prognosis, and therapy of both birch pollen allergies and birch pollen-related food allergies. 


\section{Disclosure of interest}

None declared.

\section{Author details}

${ }^{1}$ Division of Allergology, Paul-Ehrlich-Institut, Langen, Germany.

${ }^{2}$ Pathophysiology and Allergy Research and Christian Doppler Laboratory for Immunomodulation, Medical University of Vienna, Vienna, Austria.

${ }^{3}$ Department of Dermatology and Allergology, Philipps University Marburg, Marburg, Germany. ${ }^{4}$ Department of Allergology, Erasmus MC-University Medical Center, Rotterdam, the Netherlands. ${ }^{5}$ Thermo Fisher Scientific, Uppsala, Sweden.

Published: 25 July 2013

doi:10.1186/2045-7022-3-S3-O15

Cite this article as: Groh et al:: Immunoglobulin E and G4 epitopes of the major allergen of birch pollen Bet $v 1$ share residues critical for antibody binding. Clinical and Translational Allergy 2013 3(Suppl 3):015

Submit your next manuscript to BioMed Central and take full advantage of:

- Convenient online submission

- Thorough peer review

- No space constraints or color figure charges

- Immediate publication on acceptance

- Inclusion in PubMed, CAS, Scopus and Google Scholar

- Research which is freely available for redistribution

Submit your manuscript at www.biomedcentral.com/submit
Ciomed Central 